\title{
Thermal stability of some metal-palmitate soaps which find various industrial applications
}

\author{
By M.F.R.Fouda*, Elham A.A.Yousef*", S.S.Mohamed** and late Zein E.Shoeb** \\ - Inorganic Chemistry Department, National Research Centre, Cairo, Egypt \\ $*$ Fats and Oils Department, National Research Centre, Cairo, Egypt
}

\section{RESUMEN}

Estabilidad térmica de jabones metal-palmitato con diversas aplicaciones industriales

Se han preparado jabones de tiecras alcalinas y elementos de transición y orbitales " $d$ " completos por el método de la dascom posición doble mediante la reacción entre sales metálicas y pal. mitaio sodico. La estabilidad térmica de estos jabones se estudio con el fin de arrojar luz sobre su idonaidad para su uso como catalizadores o lubricantes. Se enconiró que los jabones de las tierras alcalinas son mas estables que los de transición y que los jabones con la capa " $\mathrm{d}$ " completa.

PALABRAS-CLAVE: Cafalizador - EstabWidad termica - iabán matai-palmitato - Lubricante.

\section{SUMMARY}

Thermal stability of some metal-palmitate soaps which find various industrial applications.

The soaps of alkaline earth's and transition elements and closed ' $d$ ' orbitals were prepared by the double decomposition method by the reaction between metallic salts and sodium paimitate. The thermal stability of these soaps was studied in order to throw the light on their suitability for using as catalysts or lubricants. The soaps of alkaline earth's were found to be more stable than transition and 'd' closed shell scaps.

KEY-WORDS: Catalyst - Lubricant - Meral-paimifale soap Thermal stabisty.

\section{INTRODUCTION}

Metallic soaps are a group of water-insoluble compounds containing alkaline earth's or heavy metals combined with monobasic carboxylic acids of 7 to 22 carbon atoms. These soaps find wide applications in various fields. They are used as stabilizers for plastics (1-3), as fungicides (4), catalysts (5), driers (6-7) fuel additives (8) as additive for lubricants and some pharmaceutical formularies (9) and as oil spill absorbent materials [i.e for removing of petroleum from water (10)].

The acid or anion portion of a metal soap can be varied. Typical anions currently used are rosin and tall oil fatty acids, saturated and unsaturated naturally. occurring long-chain monocarboxylic tatty acids with
7 to 22 atoms, naphthenic, 2-ethylhexanoic, and the newer synthetic tertiary acids.

Acid soaps contain free acid (positive acid number). whereas neutral (normal) soaps contain no free acid (zero acid number). That is, the ratio of acid equivalents to metal equivalents is greater than one in the acid soap and equals to one in the neutral one. The basic soap is characterized by a higher metal-to-acid equivalent ratio than the normal metal soap where particular properties are obtained by adjusting the basicity.

The present study deals with a number of neutral metallic soaps prepared and characterized by several thermal and spectroscopic techniques such as infrared spectra and X-ray diffraction patterns.

The present study aimed to investigate their molecular structure and their stability towards heat.

\section{EXPERMENTAL}

\section{Preparation of soaps}

The studied soaps were prepared by gradual addition of the stechiometric amounts of a warm solution of $10 \%$ sodium palmitate dissolved in $10 \%$ ethanol water mixture, while stirring, to $5 \%$ aqueous solution of chloride or nitrate of $\mathrm{Mg}, \mathrm{Ca}, \mathrm{Sr}, \mathrm{Ba}, \mathrm{Mn}$, $\mathrm{Fe}, \mathrm{Ni}, \mathrm{Cu}, \mathrm{Zn}$, and $\mathrm{Ag}$ until complete precipitation of the desired metallic soap. The proposed sequence for addition was followed to avoid the precipitation of the corresponding metal hydroxides.

The precipitated metallic soaps were washed thoroughly with water until the wash was free from chloride or nitrate ions. The resulted products were dried, at $40^{\circ} \mathrm{C}$ for several days until constant weight was achieved before use.

\section{Techniques and measurements}

The infrared absorption spectra, IA were measured using Lambda 40 and FTIR Spectrum 1000 respectively $(11-13)$.

$X$-ray powder diffraction for the examined compounds patterns were obtained at room temperature using a Siemens diffractometer (D 500) employing Ni-filtered $\mathrm{Cu} K \alpha$ radiation $(\lambda=1.5404 \mathrm{~A})$. The X-ray tube was operated at $36 \mathrm{KV}$ and $20 \mathrm{~mA}$ samples were finely ground and packed in a plastic 
Table I

The frequencies ( $\left.\mathrm{cm}^{-1}\right)$ of absorption maxima in the IR spectra of alkaline earth's palmitate form

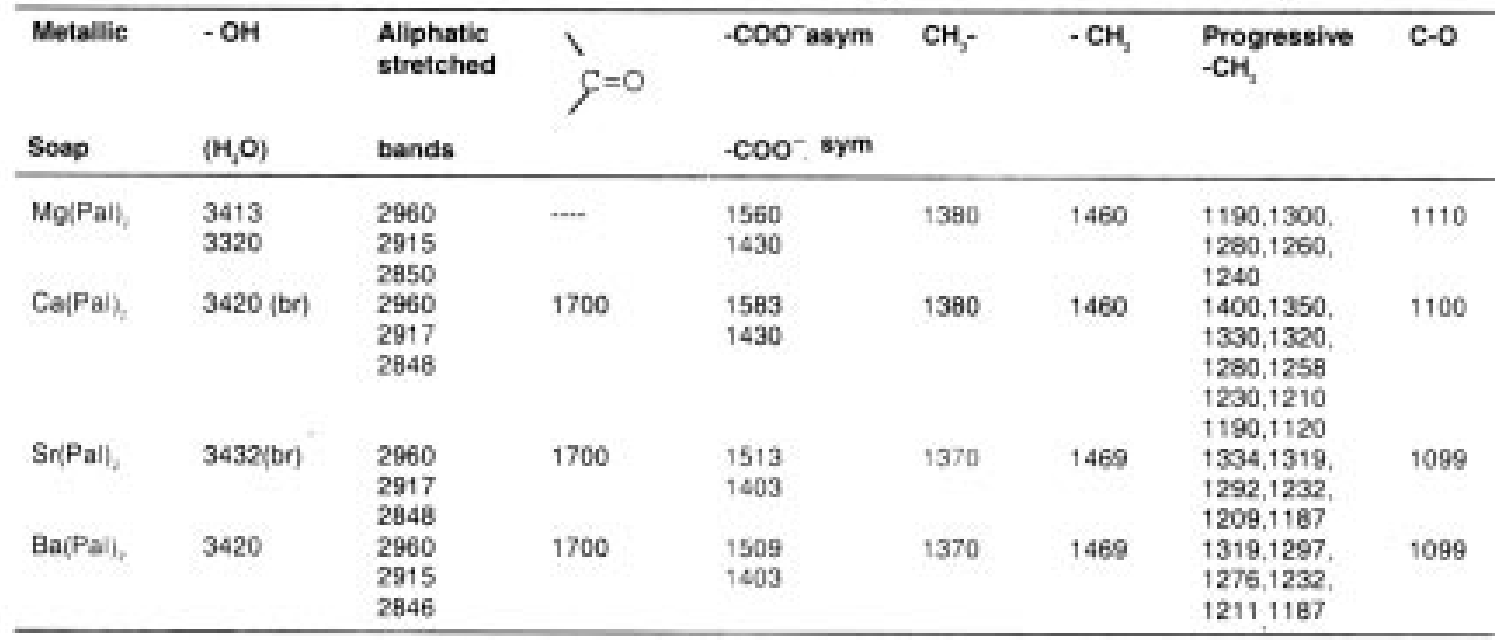

Table II

The frequencies $\left(\mathrm{cm}^{-1}\right)$ of absorption maxima in the IR spectra of transition element's palmitate form

\begin{tabular}{|c|c|c|c|c|c|c|c|c|}
\hline Motalie & $=\mathrm{OH}$ & $\begin{array}{l}\text { Alphatie } \\
\text { strenthad }\end{array}$ & $y$ & COO axym & $\mathrm{CH}_{-}$ & $\cdot \mathrm{CH}_{1}$ & $\begin{array}{l}\text { Propressive } \\
\text {-ch, }\end{array}$ & $c-0$ \\
\hline Sonp & 마이 & bands & & $\cos$ aym & & & & \\
\hline Mnval, & $\begin{array}{l}3413 \\
3320\end{array}$ & $\begin{array}{l}2500 \\
2917 \\
2643\end{array}$ & - & $\begin{array}{l}1500 \\
127\end{array}$ & 1300 & 1457 & $\begin{array}{l}1317,1800 \\
1275,1260 \\
1230,1210\end{array}$ & $\begin{array}{l}1110 . \\
t 118\end{array}$ \\
\hline Feipwis & $37 x y$ (tor) & $\begin{array}{l}2960 \\
2919 \\
2549\end{array}$ & & $\begin{array}{l}1571 \\
1420\end{array}$ & 1980 & 14se & $\begin{array}{l}1317,1300 \\
1275,1250 \\
1238,1210 \\
1195\end{array}$ & 1100 \\
\hline Nupape & 3440 pon & $\begin{array}{l}2560 \\
2917 \\
2643\end{array}$ & 1700 & $\begin{array}{l}1500 \\
1440\end{array}$ & 1360 & 1467 & $\begin{array}{l}1320,1300 \\
1290,1250 \\
1290,1210 \\
1190\end{array}$ & 1112 \\
\hline Qupan, & 3440 & $\begin{array}{l}2560 \\
2913 \\
2604\end{array}$ & & $\begin{array}{l}1543 \\
1406\end{array}$ & 1390 & 1867 & $\begin{array}{l}1320,1300 \\
1230.1260 \\
1230.1210 \\
1190\end{array}$ & +099 \\
\hline 2ndPul, & Hasti & $\begin{array}{l}2900 \\
2915 \\
2846\end{array}$ & & $\begin{array}{l}1538 \\
1396\end{array}$ & 1375 & 14ts & $\begin{array}{l}1320,1300 \\
1290,1200 \\
1238,1210 \\
1190\end{array}$ & 1100 \\
\hline $\mathrm{Ag}+\mathrm{Pd}$ & 3448 & $\begin{array}{l}2906 \\
2915 \\
2046\end{array}$ & & $\begin{array}{l}1558 \\
1517 \\
1459\end{array}$ & 1809 & $|d 7|$ & $\begin{array}{l}1350,1395 \\
1320,1300 \\
1250,1250 \\
1230,1210 \\
1+50\end{array}$ & $\begin{array}{l}1100 \\
1119\end{array}$ \\
\hline
\end{tabular}

holder. The diffraction angle (29) was scanned at rate of $2 \theta \mathrm{min}^{-1}(14)$.

The metal soaps are subjected to thermal analysis using Perkin-Elmer, 7 series thermal analysis system with a differential scanning calorimeter cell. The rate of heating was $10^{\circ} \mathrm{C} / \mathrm{min}$ in a stream of air with a flow fate of $30 \mathrm{~cm}^{3} / \mathrm{min}$.

\section{RESULTS AND DISCUSSION}

\section{Infrared spectra of palmitates}

The different palmitates were characterized by means of recording of their infrared spectra (Tables I and II). They possess the following characteristics:

(a) Presence of characteristic progressive $\left(\mathrm{CH}_{2}\right)$ bands which lie between 1150 and $1390 \mathrm{~cm}^{-1}$
(12) and a deformation one which lies at (1456-1467) $\mathrm{cm}^{-1}$.

(b) Presence of three stretch bands lie in $2960,2915 \pm 4$, and $2846 \pm 4 \mathrm{~cm}^{-1}$ of the aliphatic chain .

(c) Presence of characteristic $\mathrm{COO}^{-}$sym and $\mathrm{COO}^{-}$asym bands at $1420 \pm 20 \& 1570 \pm 10 \mathrm{~cm}^{-1}$ respectively.

(d) Appearance of characteristic bands for methyl group at 1370 or $1380 \mathrm{~cm}^{-1}$ depending on the nature of the metal.

Thermal gravimetric analysis of some metal paimitates

The different paimitates suffer from stability on heating at relatively high temperature and transform to oxide or carbonate depending on the identity of the 
Table III

Characterization of TG and DTG curves for alkaline earth's soaps

\begin{tabular}{|c|c|c|c|c|c|}
\hline \multirow{2}{*}{$\begin{array}{l}\text { Mealis } \\
\text { Seap }\end{array}$} & \multirow{2}{*}{$\begin{array}{l}\text { Therros } \\
\text { Sles }\end{array}$} & \multirow{2}{*}{$\begin{array}{l}\text { Thernal } \\
\text { Fange }\end{array}$} & \multicolumn{2}{|c|}{ Lass's } & \multirow{2}{*}{ Therral Product } \\
\hline & & & Actial & Calouloned & \\
\hline \multirow[t]{2}{*}{ WP Pal } & $\begin{array}{l}\text { dethyoten } \\
\text { skep }\end{array}$ & $50-123$ & - & & \\
\hline & 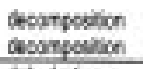 & $\begin{array}{l}450-43 \\
23445 \\
\end{array}$ & $\begin{array}{l}12.17 \\
695 \\
\end{array}$ & $\begin{array}{l}15.75 \\
7.53 \\
\end{array}$ & $\begin{array}{l}\mathrm{MgCO}_{1} \\
\mathrm{~N}_{0} \mathrm{O}\end{array}$ \\
\hline \multirow[t]{2}{*}{ Copen, } & $\begin{array}{l}\text { Setporiton } \\
\text { sep }\end{array}$ & 50.140 & - & & \\
\hline & 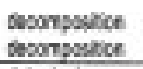 & $\begin{array}{r}4655+4977 \\
497.6025 \\
\end{array}$ & $\begin{array}{l}\text { ns. } \\
\text { ns }\end{array}$ & $\begin{array}{l}165 \\
16.17 \mathrm{~g}\end{array}$ & $\begin{array}{l}C 000 \\
0 \times 0\end{array}$ \\
\hline \multirow[t]{2}{*}{$\mathrm{S} / \mathrm{PaO}_{h_{1}}$} & $\begin{array}{l}\text { Selydabon } \\
\text { sep }\end{array}$ & GEtast & $m$ & & \\
\hline & $\begin{array}{l}\text { Secingoster } \\
\text { fermul sabily } \\
\text { cesongsites }\end{array}$ & $\begin{array}{l}4828512 \\
512+60\end{array}$ & 24.6 & 24 & 9100 \\
\hline Bupali & 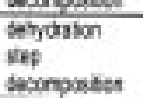 & 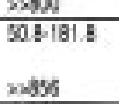 & $\begin{array}{l}174 \\
-130\end{array}$ & 30.44 & $\mathrm{BaCO}$ \\
\hline
\end{tabular}

metal as clarified in Table III. The resulting compounds were characterized by means of $\mathrm{x}$-ray diffraction patterns where they show the characteristic ' $d$ ' spacings according to ASTM (15) cards $\mathrm{N}^{\circ}$ 4-829, 28-775, 6-520, 41-373,41-1442, 4-755, 5-664,4-835, 5-661, 4-783 for $\mathrm{MgO}, \mathrm{CaO}, \mathrm{SrO}$,
$\mathrm{BaCO}_{3}, \mathrm{Mn}_{2} \mathrm{O}_{3}, \mathrm{Fe}_{2} \mathrm{O}_{3}, \mathrm{ZnO}, \mathrm{NiO}, \mathrm{CuO}$, and $\mathrm{Ag}$ respectively (Tables IV and V).

The soaps of barium palmitate and magnesium palmitate were taken as a representative example for investigation of the thermal behavior of alkaline earth soaps. The courses of TG (Thermal Gravimetry) and DTG (Derivative Thermal Gravimetry) plots of barium palmitate clarified that the soap starts to loss its water of hydration at $50.8^{\circ} \mathrm{C}$ ending at $180.8^{\circ} \mathrm{C}$ with formation of an anhydrous soap. The last compound suffers from stability at higher temperatures and transforms to the corresponding carbonate at $600^{\circ} \mathrm{C}$. The last compound transforms to the oxide at temperatures higher than $856^{\circ} \mathrm{C}$ (Figure 1).

By analogy the thermal behavior of the palmitates of $\mathrm{Mg}, \mathrm{Ca}$ and $\mathrm{Sr}$ were more or less the same as that of barium palmitate. In case of heating of Magnesium palmitate (Figure 2) the resulting of Magnesium carbonate at $400^{\circ} \mathrm{C}$ and $\mathrm{MgO}$ resulted at $>443^{\circ} \mathrm{C}$. $\mathrm{MgO}$ was confirmed by appearance of their characteristic d spacing published by ASTM (15). cards $\mathrm{N}^{\circ} 4-829$ (Figure 3 ).

Generally speaking the transformation of carbonates into the corresponding oxides in case of alkaline earth soaps depends on the heating temperature and the basicity of metal, since it is known that the carbonates of basic metals decomposed at higher temperatures i.e the

Table IV

Characteristics of $\mathrm{d}^{\circ} \mathrm{A}$ spacings of the heated metal palmitat product and of silver palmitate

\begin{tabular}{|c|c|c|c|c|c|c|c|c|c|c|c|c|c|c|c|c|c|c|c|c|c|}
\hline \multicolumn{2}{|c|}{$U_{;} ; 0$} & \multicolumn{2}{|c|}{$\mathrm{CaO}$} & \multicolumn{2}{|c|}{$5 r 0$} & \multicolumn{2}{|c|}{$\mathrm{BaCO}$, } & \multicolumn{2}{|c|}{$\mathrm{M}=\mathrm{O}_{1}$} & \multicolumn{2}{|c|}{$\mathrm{Fe}_{0}, \mathrm{O}_{1}$} & \multicolumn{2}{|c|}{$2 n 0$} & \multicolumn{2}{|c|}{ No } & \multicolumn{2}{|c|}{$Q 00$} & \multicolumn{2}{|c|}{$\mathrm{Ag}$} & \multicolumn{2}{|c|}{ AgPal } \\
\hline OA & $\pi^{\circ}$ & $d A$ & $n$ & EA & $n$ & dA & W & $d A$ & W & $d A$ & in & $\Phi A$ & $\bar{F}$ & GA & $\bar{F}$ & o'A & in & $d A$ & $\pi$ & $d A$ & W \\
\hline 2.43 & 135 & 304 & 100 & 30 & 56 & 45 & 8 & 38 & 33 & 2.66 & 47.5 & 282 & 898 & 241 & 863 & 275 & 129 & 235 & 100 & 21.5 & 100 \\
\hline 211 & 100 & 25 & 19 & 259 & 48 & 37 & 81 & $2 \pi$ & 100 & 252 & 100 & 261 & 648 & 209 & 100 & 252 & 100 & 205 & 30 & 146 & 920 \\
\hline 1.89 & 432 & 228 & 246 & $1 B 2$ & 100 & 360 & 425 & 239 & 294 & 200 & 191 & 248 & 100 & 1.47 & 50 & 232 & 943 & 1.44 & 39 & 109 & 47.6 \\
\hline 127 & 108 & 200 & 801 & 150 & 22 & 322 & 100 & 200 & 235 & 1.76 & 143 & 191 & 31.8 & 125 & 20 & 187 & 27.1 & 123 & 30 & 871 & 429 \\
\hline 121 & 135 & 1.91 & 21.7 & 1.48 & 32 & 300 & 16 & 1.52 & 118 & 1.51 & 286 & 1,83 & 48.9 & 121 & 15 & 1.71 & 99 & 1.18 & 8.6 & 73 & 167 \\
\hline & & 187 & 28.1 & 120 & 68 & 274 & 108 & 1.86 & 173 & 1.48 & 301 & 1.48 & 33 & & & 1.58 & 143 & & & 5.5 & 95 \\
\hline & & & & $t .18$ & 36 & 26 & 5.4 & 1.68 & 353 & & & 1.41 & 68 & & & 1.51 & 186 & & & 460 & 9.5 \\
\hline & & & & & & $2 \sqrt{2}$ & 324 & & & & & 1.38 & 30.7 & & & 1.42 & 11.4 & & & 452 & 11.9 \\
\hline & & & & & & 2.5 & 189 & & & & & 1.36 & 148 & & & 138 & 17.1 & & & 348 & 48 \\
\hline & & & & & & 258 & 189 & & & & & 1.3 & 68 & & & 1.3 & 57 & & & 345 & 48 \\
\hline & & & & & & 23 & 54 & & & & & 123 & 6.8 & & & 127 & $B S$ & & & & \\
\hline & & & & & & 21 & 27 & & & & & & & & & & & & & & \\
\hline & & & & & & 200 & 189 & & & & & & & & & & & & & & \\
\hline & & & & & & 201 & 243 & & & & & & & & & & & & & & \\
\hline & & & & & & 1.94 & 541 & & & & & & & & & & & & & & \\
\hline & & & & & & 1.90 & 351 & & & & & & & & & & & & & & \\
\hline & & & & & & 1.85 & 81 & & & & & & & & & & & & & & \\
\hline & & & & & & 17 & 8.1 & & & & & & & & & & & & & & \\
\hline & & & & & & 1.65 & 81 & & & & & & & & & & & & & & \\
\hline & & & & & & 1.63 & 81 & & & & & & & & & & & & & & \\
\hline & & & & & & 1.51 & 162 & & & & & & & & & & & & & & \\
\hline & & & & & & 1.86 & 10.8 & & & & & & & & & & & & & & \\
\hline & & & & & & 1.51 & 13.5 & & & & & & & & & & & & & & \\
\hline & & & & & & 1.37 & 162 & & & & & & & & & & & & & & \\
\hline & & & & & & 136 & 108 & & & & & & & & & & & & & & \\
\hline & & & & & & 1.33 & 10.8 & & & & & & & & & & & & & & \\
\hline
\end{tabular}

- $V^{2}$ Shows the ratio of the height of the given peak to the height of the most intense peak in the given pattern. 
Table V

Characteristics of $\mathrm{d}^{\circ} \mathrm{A}$ spacings of some metal oxides, silver and of silver paimitate as astm cards

\begin{tabular}{|c|c|c|c|c|c|c|c|c|c|c|c|c|c|c|c|c|c|c|c|c|c|}
\hline \multicolumn{2}{|c|}{$u_{;} 0$} & \multicolumn{2}{|c|}{$\mathrm{CaO}$} & \multicolumn{2}{|c|}{50} & \multicolumn{2}{|c|}{$\mathrm{BeCO}$} & \multicolumn{2}{|c|}{$\operatorname{Vn}, 0$} & \multicolumn{2}{|c|}{$\mathrm{Fe}, 0$} & \multicolumn{2}{|c|}{270} & \multicolumn{2}{|c|}{ NiD } & \multicolumn{2}{|c|}{600} & \multicolumn{2}{|c|}{ Ai } & \multicolumn{2}{|c|}{ ApPal } \\
\hline$d A$ & in & $d A$ & $W^{2}$ & dA & $W^{\circ}$ & $d A$ & $W^{2}$ & $d A$ & $W^{\circ}$ & $d A$ & $n$ & $8 A$ & $\bar{W}$ & $d A$ & $W^{2}$ & $d A$ & $W^{2}$ & $d A$ & i & $d A$ & $u^{*}$ \\
\hline 2431 & 9 & 3 & 100 & 296 & 西 & 449 & 9 & 384 & 11 & 295 & 29 & 2816 & 62 & 241 & 79 & $2 \pi$ & 11 & 2359 & 100 & 21.4 & 100 \\
\hline 2.106 & 100 & 252 & 24 & 2581 & 8 & 3691 & 102 & 271 & 100 & 252 & 100 & 200 & 59 & 2000 & 100 & 253 & 47 & 2044 & 46 & 145 & 92 \\
\hline 1,499 & 74 & 228 & 19 & 1.625 & 100 & 3646 & 49 & 235 & 16 & 2.09 & 2 & 2.476 & 100 & 1.476 & 81 & 232 & 100 & 1.445 & 41 & 109 & 31 \\
\hline 127 & 7 & 200 & 57 & 1.550 & 73 & 322 & 71 & 2 & 11 & 1.7 & 18 & 1911 & 36 & 1.250 & 27 & 1.6000 & 32 & 123 & 50 & 8.75 & 29 \\
\hline 1215 & 21 & 1.91 & 94 & 1.49 & 30 & 3000 & 6 & 1.92 & 1 & 1.51 & 52 & 1626 & 61 & 1.206 & 23 & 1.71 & 11 & 1.179 & 24 & 732 & 23 \\
\hline & & 1.88 & 96 & 1.29 & 5 & 274 & 3 & 1.845 & 13 & 1,48 & 90 & 1477 & 59 & & & 1.58 & 21 & & & 5.48 & 6 \\
\hline & & & & 1.184 & 39 & 267 & 3 & 1.66 & 46 & & & 1.407 & $t 1$ & & & 1.506 & $\$ 2$ & & & 459 & 65 \\
\hline & & & & & & 262 & 30 & & & & & 1379 & 50 & & & 1.418 & 20 & & & 452 & 6 \\
\hline & & & & & & 261 & 20 & & & & & 1359 & 28 & & & 1.375 & 30 & & & 3.48 & 98 \\
\hline & & & & & & 256 & 37 & & & & & 13 & 6 & & & 1.3 & 13 & & & 3.45 & 97 \\
\hline & & & & & & 230 & 3 & & & & & 1238 & 10 & & & $1.2 \%$ & 11 & & & & \\
\hline & & & & & & 2123 & 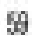 & & & & & & & & & & & & & & \\
\hline & & & & & & 2009 & $2 \approx$ & & & & & & & & & & & & & & \\
\hline & & & & & & 200 & 27 & & & & & & & & & & & & & & \\
\hline & & & & & & $200 \mathrm{~A}$ & 53 & & & & & & & & & & & & & & \\
\hline & & & & & & 1.94 & 44 & & & & & & & & & & & & & & \\
\hline & & & & & & 184 & 8 & & & & & & & & & & & & & & \\
\hline & & & & & & 182 & 4 & & & & & & & & & & & & & & \\
\hline & & & & & & 1709 & 4 & & & & & & & & & & & & & & \\
\hline & & & & & & 160 & 2 & & & & & & & & & & & & & & \\
\hline & & & & & & 1052 & 22 & & & & & & & & & & & & & & \\
\hline & & & & & & 150 & 12 & & & & & & & & & & & & & & \\
\hline & & & & & & 154 & 5 & & & & & & & & & & & & & & \\
\hline & & & & & & 137 & 11 & & & & & & & & & & & & & & \\
\hline & & & & & & 136 & 22 & & & & & & & & & & & & & & \\
\hline & & & & & & 135 & 22 & & & & & & & & & & & & & & \\
\hline
\end{tabular}

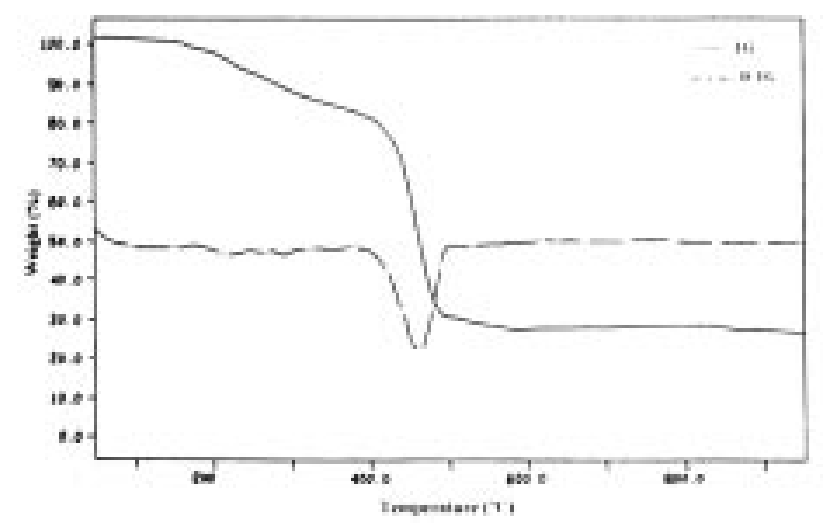

Figure 1

TO and DTG of Barium palmitate (neating rate $=10^{\circ} \mathrm{C} / \mathrm{min}$ )

decomposition temperatures of alkaline earth carbonate increase in the following sequence $\mathrm{MgCO}_{3}<\mathrm{CaCO}_{3}<\mathrm{SrCO}_{3}<\mathrm{BaCo}_{3}(16)$.

The identity of carbonates was also confirmed by the presence of their characteristic $\mathrm{CO}_{3}{ }^{2}, \mathrm{C}=\mathrm{O}$ and $\mathrm{C}-\mathrm{O}$ bands (Table VI) and disappearance of that characteristic for methyl group, progressive $-\mathrm{CH}_{2}$ groups and aliphatic chain.

As can be seen from Table III and Figures 1 and 2 the temperature of conversion of such compounds to

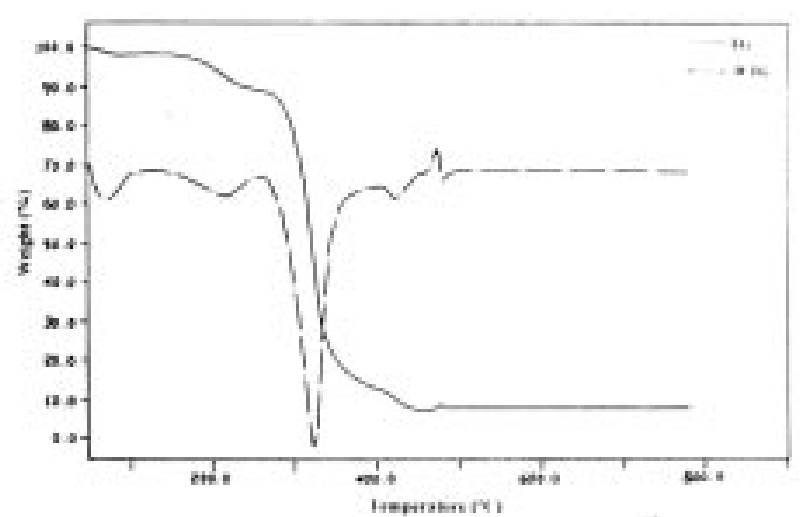

Figure 2

TG and DTG of Magnesium palmitate (heating rate $=10^{\circ} \mathrm{C} /$ min)

the corresponding carbonates and oxides was found to increase with increasing the basicity of the alkaline earth's metals as could be expected.

The palmitates of transition elements and closed 'd' orbitals suffer from stability by heating and show different decomposition steps not isolated with a reasonable range of constancy.

The heating process of different transition elements leads to formation of the corresponding oxide $\mathrm{Fe}_{2} \mathrm{O}_{3}, \mathrm{Mn}_{2} \mathrm{O}_{3}, \mathrm{NiO}, \mathrm{CuO}$ and $\mathrm{ZnO}$ as end 


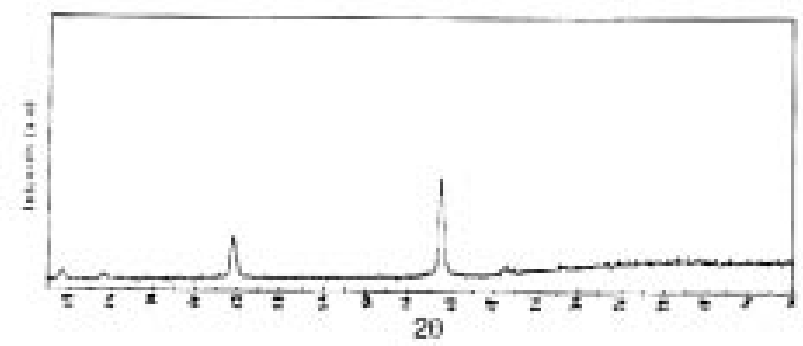

Figure 3

X-Ray diffraction pattern of Magnesium Oxide $(\mathrm{M} \infty \mathrm{O})$.

Table VI

The frequencies $\left(\mathrm{cm}^{-1}\right)$ of absorption maxima in the IR spectra of alkaline earth's carbonated form

\begin{tabular}{|c|c|c|c|c|c|c|}
\hline \multirow{2}{*}{$\begin{array}{l}\text { Meta } \\
\text { Ilic } \\
\text { Sosp }\end{array}$} & \multicolumn{6}{|c|}{ Frequenty $\mathrm{cm}^{-1}$} \\
\hline & $\mathrm{CO}^{-2}$ & $C=0$ & c.o & $\begin{array}{c}\text { Aliphatic } \\
\text { bands }\end{array}$ & $\underset{\text { progressive }}{\mathrm{CH}_{2}}$ & $-\mathrm{CH}_{\mathrm{s}}$ \\
\hline $\mathrm{MgCa}_{3}$ & $1400-1468$ & 1700 & - & - & - & - \\
\hline $\mathrm{CaCa}_{3}$ & $1428|\mathrm{br}\rangle$ & 1797 & - & - & - & - \\
\hline $\mathrm{SrCO}_{3}$ & 1461 & 1773 & 1071 & - & - & - \\
\hline $\mathrm{BaCO}$ & 1437 & 1754 & 1059 & - & - & - \\
\hline
\end{tabular}

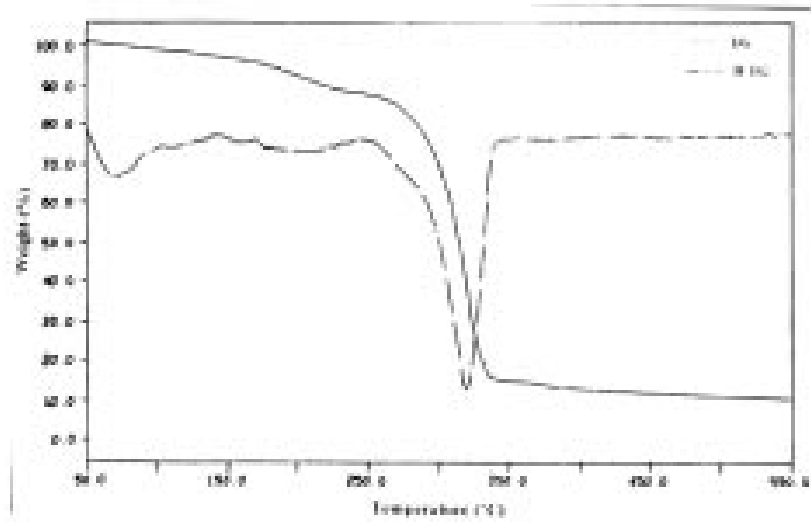

Figure 4

TG and DTG of Nickel paimitate (heating rate $=10^{\circ} \mathrm{C} / \mathrm{min}$ )

products (Table VII and Figure 4) except in case of silver palmitate that produces silver metal upon heating. This phenomenon may be taken place due to silver oxide transformation into silver metal upon heating at temperature higher than $600^{\circ} \mathrm{C}$. X-ray diffraction of silver and silver palmitate were confirmed by appearance of their characteristic ' $d$ ' spacing published by ASTM cards $\mathrm{N}^{\circ}$ 4-783 and 4-34 respectively (Figures 5,6 Table IV).
Table VII

Characterization of TG and DTG curves for transition element soaps

\begin{tabular}{|c|c|c|c|c|c|}
\hline \multirow{2}{*}{$\begin{array}{c}\text { Metallic } \\
\text { Sosp }\end{array}$} & \multirow{2}{*}{$\begin{array}{c}\text { Thermal } \\
\text { Step }\end{array}$} & \multirow{2}{*}{$\begin{array}{c}\text { Thermal } \\
\text { Aange }\end{array}$} & \multicolumn{2}{|c|}{ Lossts } & \multirow{2}{*}{$\begin{array}{l}\text { Thermal } \\
\text { Produet }\end{array}$} \\
\hline & & & Actual & Calculated & \\
\hline \multirow[t]{2}{*}{$\mathrm{Mr} \mathrm{Pafl}_{2}$} & $\begin{array}{l}\text { detydration } \\
\text { step }\end{array}$ & $50-125$ & - & & \\
\hline & decomposison & $>2500$ & 6.96 & 753 & $\mathrm{Mn}_{2} \mathrm{O}_{3}$ \\
\hline \multirow[t]{2}{*}{ Fospalla } & $\begin{array}{l}\text { dehydrason } \\
\text { step }\end{array}$ & $50-186$ & - & & \\
\hline & decomposabon & $2>-424.5$ & 13 & 14 & $\mathrm{Fe}_{2} \mathrm{O}_{3}$ \\
\hline \multirow[t]{2}{*}{$\mathrm{N} / \mathrm{Pa} / 2$} & $\begin{array}{l}\text { dehyoration } \\
\text { step }\end{array}$ & $52-137$ & - & & \\
\hline & decompostion & $\gg \$ 500$ & 127 & 13.11 & NIO \\
\hline \multirow[t]{2}{*}{ Cupale } & $\begin{array}{l}\text { dehydration } \\
\text { step }\end{array}$ & 51.79 .125 .5 & - & & \\
\hline & decomposition & $>>450$ & 126 & 138 & CUO \\
\hline \multirow[t]{2}{*}{$\mathrm{Zn}\left(\mathrm{Pal}_{2} \mathrm{C}\right.$} & $\begin{array}{l}\text { dehydration } \\
\text { step }\end{array}$ & $50.75-116.2$ & - & & \\
\hline & decomposition & $>>483.25$ & 12.6 & 14.1 & $\mathrm{ZnO}$ \\
\hline \multirow[t]{2}{*}{$A g-P a l$} & $\begin{array}{l}\text { dehydration } \\
\text { sesep }\end{array}$ & 50.116 .2 & - & & \\
\hline & decompositon & $>>468.9$ & 32.2 & 2969 & $\mathrm{Ag}$ \\
\hline
\end{tabular}

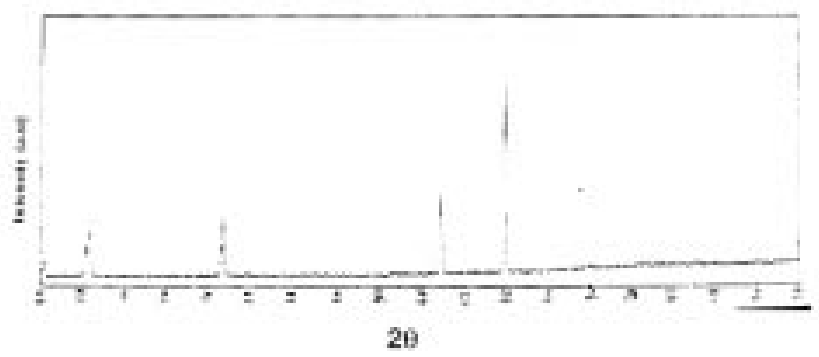

Figure 5

X-Pay diffraction pattern of Silver Metal

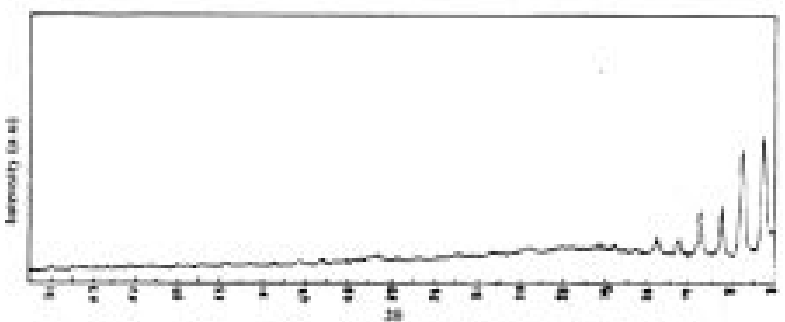

Figure 6

$X$-Ray diftraction pattern of Sitver Palmitate 


\section{CONCLUSIONS}

1. The thermal behavior of different types of palmitates is considered as an excellent guide before their use in different applications such as catalysts, and as fuel additives .

2. The palmitates of alkaline earth's specially of barium were found to be more stable than those of transition elements so that they can be used as lubricants due to their stability towards heating during manufacturing wire drawing .

\section{REFERENCES}

1. Werner,E ., Fritz,L., Dieter, K. and Kurt, W.(1992). Preparation of metal 2.2. bis (hydroxymethyl) propionates as stabilizers of thermoplastic. Ger,Otfen.D.E.4, 006,883, Appl 05Mar 1990;6pp. - C.A. 116. 20686 (Ger).

2. Linder, R.A and Koller, L.L (1997). Injection moldings from vinyl polymer containing lubricant and stabilizers. USA Patent, 13pp CODEN: PIXXD 2 PI: Wo 9611228 Al960418. Al Wo 95- US 12280 950922. PRAl US 94-320467 941007.C.A.125, 88165.

3. Chang. P.I.,Ray,C.D. and Gross, A.W.(1997). "Thermoplastics composition suitable for composting ". Tredegar Industries,Inc., USA. U.S., 20pp CODEN. USXXAM.PI US 5258422A 931102 AI US 92-878738 920505. C.A.120. 136212.

4. Fredrick, S.S. and Hellmut, K.E. (1993). Fatty acids metals as non-phytotoxic fungicides with residual activity. (Neudorft,W.,G.m.b.H.K.-G.) PCT Int.Appl. Wo93 13,661, us Appl 818,613,10 Jan 1992; 34 pp. C.A.119, 111286 .

5. Kirk, O, (1979). Encyclopedia of chemical technology, Third Edition. Awiley- Interscience Publication New.York. 8, 43,44.
6. Demande, Fr, (1974), 2,213,973 (To Hardman\& Holden Ltd).

7. Turner, J.H.W. (1974). 2,402,039 (To Hardman\& Holden Lid).

8. Ogawa, H. (1975). Additive for a Mineral Oil Especially for a heavy Oil, Japan $74 \quad 42,886$, Appl.67 83,735.27Dec 1967:5pp.C.A.82, 158567

9. Marwaha. S.B; Rubinstein, M.H. (1988). StructureLubricity evaluation of Magnesium Stearale International-Journal-of-Pharmaceutics 43, 249.

10. Anthony, V.C. (1988). Oils Spill Absorbent Material. U.S. Patent No.4. 780.518 .

11. Arenase,A.S., Garcia, M.V., Redondo, M.I., Cheda, JA.R, Roux, M.V. and Turrion,C. (1995) Thermophysical study of lead (ii) $n$-alkanoates by DSC,optiacl microscopy. FTIR and Raman spectroscopy. Liq.Cryst, 18(3), 431-41.

12. Yasushi, K. and Ayohei, .M. (1961). Studies on the structure of Metal Soaps. Dep of Chem, Kyushu Univ Ser.4, No.1.

13. Redondo, M.I., Garcia, M.V., Gonzalez,T.M.J, and Cheda, J.A.R (1995). Spectroscopic study of phase transition of $\mathrm{Cu}^{+2} \mathrm{n}$-alkanoates. Spectrochimica. Acta, part A 51A(3), 341-347.

14. Vold,R.D and Hattiangdi(1949) .Characterization of Heavy metals soaps by X- Ray Diffraction. Industrial and Engineering Chemistry 41, 2311.

15. Annual Book of ASTM D- 4-829, 28-775, 6-520, $41-373,41-1442,4-755,5-664,4-835,5-661,4-783$ and 4-34, Washington.

16. Robert C. W (1982), CRC Hand Book of Chemistry and Physics $62^{\text {nd }}$ edition CAC Press, Inc . Boca Raton. Florida . 